\title{
STUDIES ON SECONDARY MALE GENITALIA OF THE TYPE SPECIES OF SOME DRAGONFLIES (ODONATA: ANISOPTERA: LIBELLULIDAE)
}

\author{
Jagbir S. Kirti and Archana Singh* \\ Department of Zoology, Punjabi University, Patiala, Punjab 147002, India \\ *Email: archu_speak@yahoo.co.in
}

\begin{abstract}
The secondary male genitalic characters of 11 type species of family Libellulidae have been examined and studied in considerable details. The taxonomic significance of the genitalic features of these species has been highlighted.

\author{
KEYWORDS \\ Dragonflies, Libellulidae, secondary male genitalia
}

AbBreviations

AL - Apical lobe; B - Barb; CN - Cornua; CP - Central plate; DH - Dorsal hood; DS - Distal segment; F - Flagellum; FF - Flagellar flap; GL - Genital lobe; H - Hamule; HS - Housing; IL - Inner lobe; L - Lamina; LL - Lateral lobe; ML - Medial lobe; MP - Medial process; MS - Middle segment; $P$ - Penis; PS - Proximal segment; $T_{2}$ - Second abdominal tergite; VS - Vesicula spermalis; ZSI Zoological Survey of India.
\end{abstract}

Insect genitalia commonly show much interspecific variation, even between closely related species. Odonata are practically unique among winged insects in that the primary genitalia do not meet during copulation. In addition to that, the male possesses another set of copulatory apparatus, the secondary genitalia, on the ventral aspect of second and third abdominal segments, which shows the same variation and function as the primary genitalia in other group of insects. Cowley (1937) in his communication on the genitalia of family Chlorocyphidae laid stress on the point of using the genitalia along with other characters in the taxonomic studies of odonates. Though, Fraser (1936) while characterizing different species in the 'Fauna of British India', gave due importance to various morphological taxonomic characters on head, thorax, legs, wings and abdomen, he failed to do justice while treating the genitalic features. Among older descriptions of anisopteran genital structures, those by Thompson (1908), Schmidt (1915), Whedon (1918) and Kennedy (1922) are some of the most useful. The significance of external genitalia in the odonate taxonomy has been realized for quite some time now by some Indian workers such as Prasad and Srivastava (1960), Khan (1969, 1972, 1973, 1974, 1976), Lahiri (1987), Prasad (1988), and, Andrew and Tembhare (1993). But, as far as the Indian species are concerned, very little has been investigated so far. However, Miller (1981, 1982, 1984, 1988, 1990, 1991a, 1991b, 1995) through his valuable contributions on libellulid dragonflies highlighted the value of genital structures in the discrimination of the species and genera. His work was confined to species from foreign lands. None of the above listed workers have described the male genitalic attributes in depth and in a detailed manner. These considerations necessitated the authors to undertake more detailed observations on the structure of male genitalia in 11 type species belonging to different genera of family Libellulidae, all collected from the various far flung localities of northwestern India. The terminology for naming the various parts of the male copulatory apparatus has been followed from Chao (1953) and Miller (1991a).
The genital parts which have been considered taxonomically important include lamina, hamule, genital lobe and penis. Emphasis has been laid on the course of variations within the group exhibited by the following components:

(a) Lamina - It is a ventrally extended medial region at the anterior end of second abdominal sternite.

(b) Hamules - They show considerable interspecific and intergeneric variations and are of much use in taxonomic studies of dragonflies. A pair of them are present in family Libellulidae and assist in maintaining proper positions in copulation.

(c) Genital lobes - These are ventral extensions of second abdominal tergite surrounding the vesicula spermalis and are characteristic of family Libellulidae. They probably serve protective and sensory functions.

(d) Penis - There is remarkable diversity in the form of penis structure at specific level. It is divided into four segments, viz., vesicula spermalis/segment first, proximal segment/segment second, middle segment/segment third and distal segment/ segment fourth. The distal segment is a highly variable structure and offers several characters of taxonomic value that can be used at specific and generic levels. The segment bears at its apex an assortment of lobes, which are modified in different species.

\section{Materials and Methods}

The adult dragonflies were collected with the help of insect collecting net from different localities of northwestern states of India in different seasons from August 1997 to October 2000. The surveyed areas included both plains and hilly places up to an altitude of $2,725 \mathrm{~m}(9,000 \mathrm{ft})$. The habitats surveyed included perennial ponds, temporary monsoon ponds, cemented garden tanks, fast flowing riverine streams, paddy fields and lakes. Some individuals of the species such as Zyxomma petiolatum Rambur, Bradinopyga geminata (Rambur), Tholymis tillarga (Fabricius) and Pantala flavescens (Fabricius) were also collected from light sources. Collected adult dragonflies were killed with ethyl acetate vapours in the killing bottle incase of teneral specimens 
or put alive into triangular paper packets and starved to death. The dead specimens were then bristled, pinned, stretched, dried and preserved. To examine the male genitalic structures, the first three abdominal segments were cut off either from the fresh specimens or dried ones. However, in latter case, the dragonflies were relaxed in insect relaxing box for 12 hours before detaching the abdomen. After detaching the abdomen, the remaining specimens were carefully saved on their pins with collection data for future reference. The detached abdomen was put in $10 \% \mathrm{KOH}$ overnight to soften the chitin and for dissolving the muscles. The potashed material was washed in distilled water containing few drops of glacial acetic acid. The dissection of the abdomen was done in 50\% alcohol to have a clear view of different genitalic attributes. After proper dehydration, the material was preserved in homeopathic vials containing a mixture of ethyl alcohol and glycerine in the ratio of $4: 1$. Each vial was marked with a printed label bearing a serial number of the specimen and name of the species. The sketches of the genitalia were made with the help of a graph eyepiece under binocular and microscope at different magnifications. At the first instance, the diagrams were drawn keeping the whole genitalia intact. The individual structures such as hamules and penis were later separated out and drawn at higher magnifications for describing these in detail.

\section{Tholymis tillarga (Fabricius)}

Fabricius, 1798. Ent. Syst. Suppl., 1798: 285. (Figs. 1-5) Lamina hood-shaped projecting, shallowly arched, clothed with numerous very long and slender setae; hamule with indistinct base, but well developed long anterior hook, furnished with densely packed long setae; genital lobes broad, but small with apical border somewhat rectangular, bearing moderately long setae; vesicula spermalis small, flask shaped, setosed on either side of middorsum; penis with middle and distal segments fused together, latter wedge shaped; lateral lobes large, flattened plate like structures, meeting distally in resting penis, enclosing a prominent ' $c$ '-shaped housing, latter concealing a long flagellum and a pair of bristled cornua; flagellum bifurcated for distal $1 / 4$ of its length, each part terminating in a broadened and flattened spatulate region bearing serrations at apical margin; spines of cornua multipronged and orientated along long axis of each cornua, but pointing proximally in distal part; apical lobe inflatable and spinose, bearing tile like scales with serrated margins.

\section{Zyxomma petiolatum Rambur}

Rambur. 1842. Hist. Nat Ins. Nevrop., 1842: 30. (Figs. 6-10) Lamina depressed, slightly notched along free margin, bearing very long slender setae both on dorsum and along free posterior margin; hamule with small base and well-developed anterior hook furnished with small and moderately long setae; genital lobes small and broad with apical margin slightly wavy, setosed with small and fine setae; vesicula spermalis flask shaped, broad, moderately sclerotized, bearing long slender setae on either side of mid-dorsum; penis with middle and distal segments fused together; lateral lobes large flattened, lateral plate like structures, meeting distally in resting penis, concealing a long flagellum and a pair of cornua in a 'c'-shaped housing; flagellum bifurcated throughout, each branch ending in a large barb, helically twisted
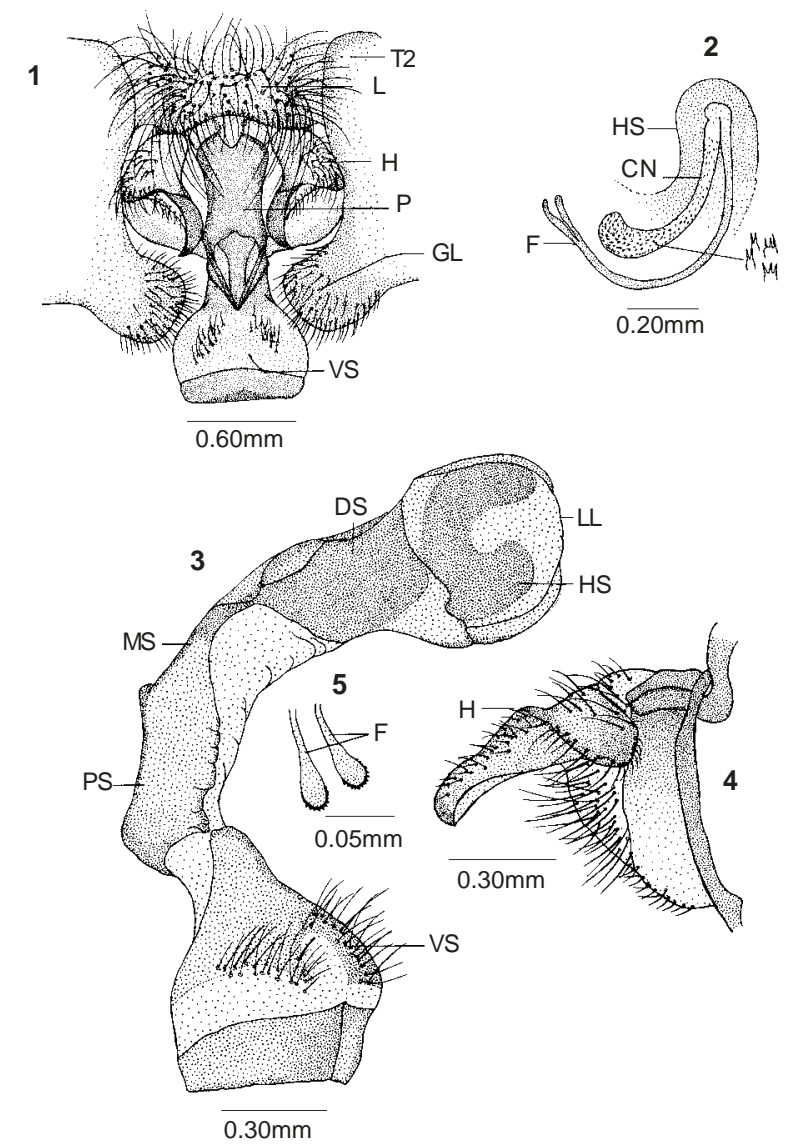

Figures 1-5. Male genitalia of Tholymis tillarga 1 - Male genitalia (intact); 2 - Flagellum+cornua (housing); 3 - Penis (lateral view); 4 - Hamule (lateral view); 5 - Apex of flagellum

membrane attached to each branch along its outer margin; cornua slightly broadened distally and spinose, spines acutely pointed, directed distally but on reaching the most distal region directed proximally; apical lobe inconspicuous and spinose.

\section{Acisoma panorpoides panorpoides Rambur}

Rambur, 1842. Hist. Nat. Ins. Nevrop., 1842: 28. (Figs. 11-15)

Lamina moderately sclerotized, deeply notched medially, bearing short setae on dorsum and long slender ones along posterior free margin; hamule with anterior border sinuous and setosed, acutely pointed at apex ending in a spine, separated with a deep cleft from posterior base, latter tapering towards apex when viewed laterally and truncated when viewed dorsally; genital lobes black, slightly truncated at apices with margins serrated, furnished with stiff, short spine like setae; vesicula spermalis black with sclerotization, besetted with few slender setae, middorusm less sclerotized and denticulate; penis with middle and proximal segments well demarcated; lateral lobes long and rectangular, fused with medial process along its inner lateral surface, anteroapical margin bristled; medial process modified to form three pairs of lobes, all furnished with densely packed and acutely pointed long spine like bristles; apical lobe squarish in outline, small, inflatable and very spinose. 


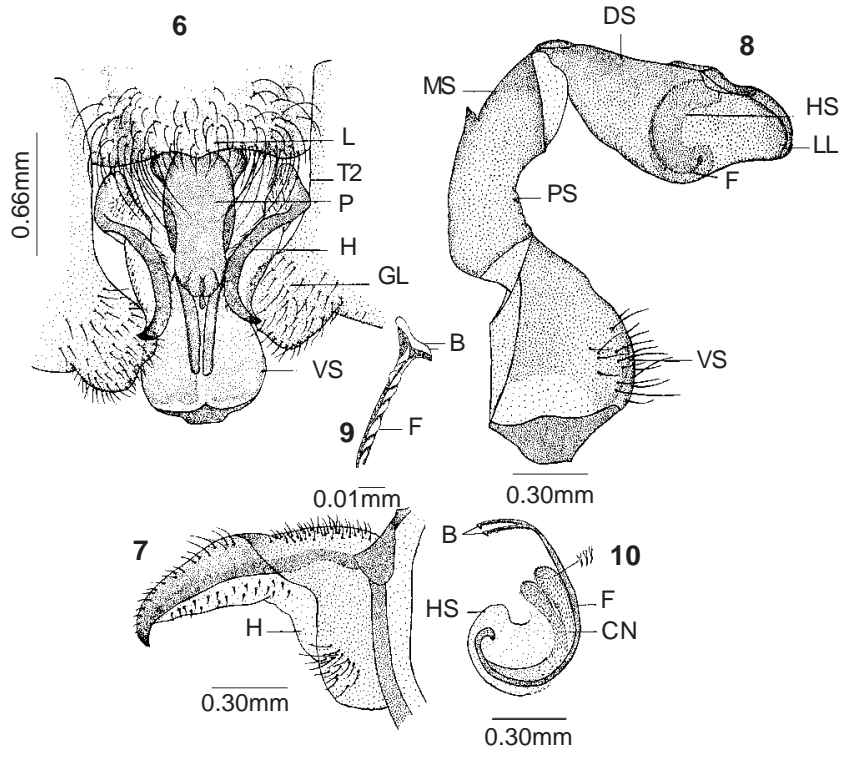

Figures 6-10. Male genitalia of Zyxomma petiolatum 6 - Male genitalia (intact); 7 - Hamule (lateral view); 8 - Penis (lateral view); 9 - Apex of flagellum; 10 - Flagellum and cornua (housing)

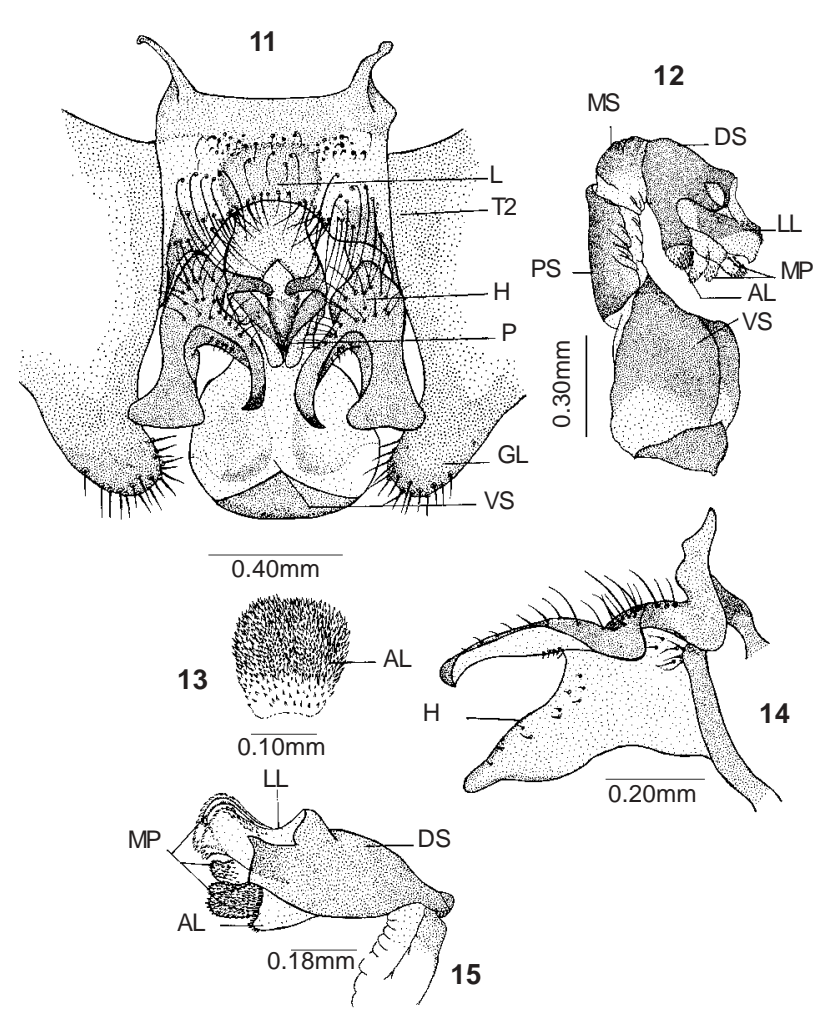

Figures 11-15. Male genitalia of Acisoma panorpoides panorpoides

11 - Male genitalia (intact); 12 - Penis (lateral view);

13 - Apical lobe (dorsal view); 14 - Hamule (lateral view); 15 - Distal segment of penis (lateral view)

\section{Brachydiplax sobrina (Rambur)}

Rambur, 1842. Hist. Nat. Ins. Nevrop., 1842: 114. (Figs. 16-19) Genitalia quite large and conspicuous in lateral profile; lamina deeply sclerotized with posterior free margin deeply cleft into two spoon shaped lobes, bearing inconspicuous small setae along margin, lobes projecting at right angle to body; hamule scoop shaped in appearance, with short, inwardly directed distally curled anterior hook, posterior base well developed and broad; genital lobes truncated at apices, bearing tuft of short and stout setae anteroapically, directed upwards; vesicula spermalis swollen, flask shaped, bearing few setae apicolaterally; penis with middle and proximal segments well demarcated; lateral lobes inconspicuous and less sclerotized; medial process inflatable, bearing a pair of inner lobes and a single median horn like lobe standing perpendicular to surface, inner lobes rounded with apices tapering, directed outwards and upwards, all lobes furnished with numerous multibarbed bristles; apical lobe small, bearing acutely pointed spines.

\section{Selysiothemis nigra (Van der Linden)}

Van der Linden, 1825. Monogr., 1825: 16. (Figs. 20-23) Lamina very depressed, slightly visible from lateral profile, broadly but shallowly arched, besetted with numerous moderately long setae, more dense along posterior border;
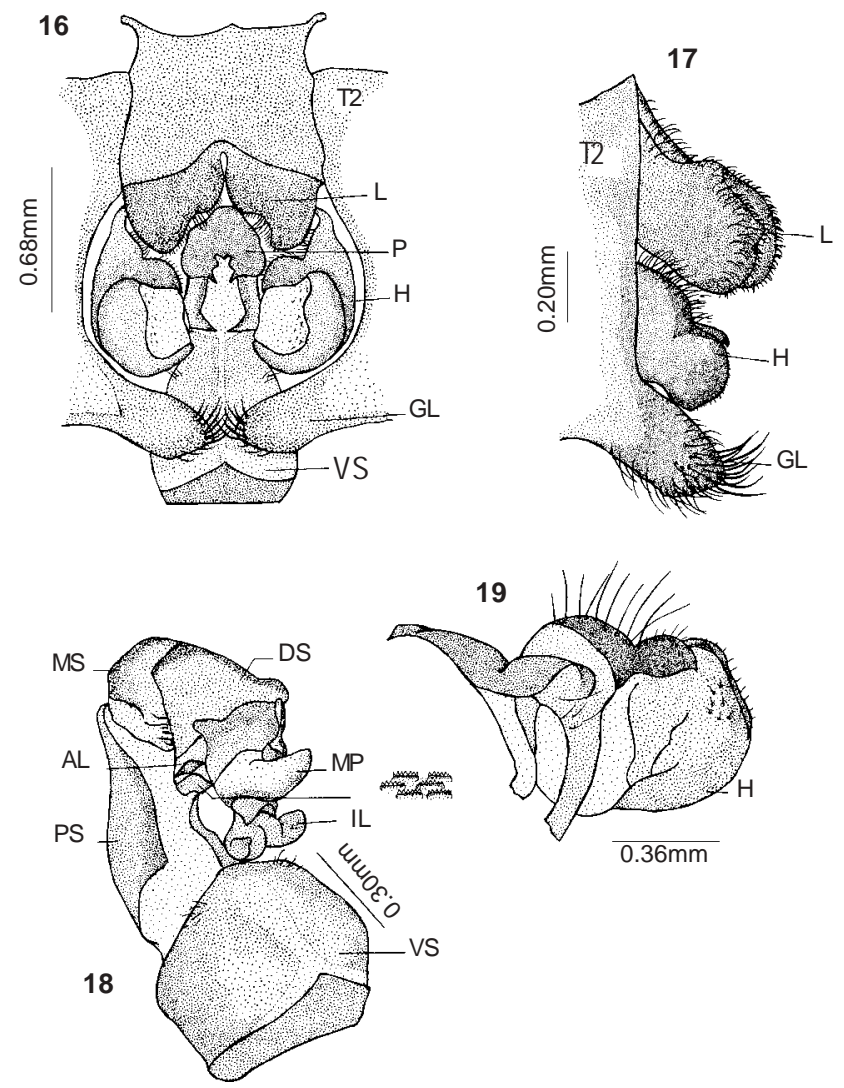

Figures 16-19. Male genitalia of Brachydiplax sobrina 16 - Male genitalia (intact); 17 - Male genitalia (lateral view); 18 - Penis (lateral view); 19 - Hamule (lateral view) 
hamule lacking a distinct base, apex produced into a short, incurved black hook; genital lobes small, apicoposterior border straight, furnished with small and slender setae; vesicula spermalis small and globular bearing thinly scattered setae on middorsum; penis with distal segment well demarcated from middle segment; lateral lobes broadly flattened, large structures concealing medial process, latter with central plate deeply sclerotized, a pair of widely spaced globular inner lobes bearing multipronged bristles; apical lobe less inflatable and moderately sclerotized structure; inner surface of lateral lobes and apical lobe also furnished with numerous multipronged bristles.
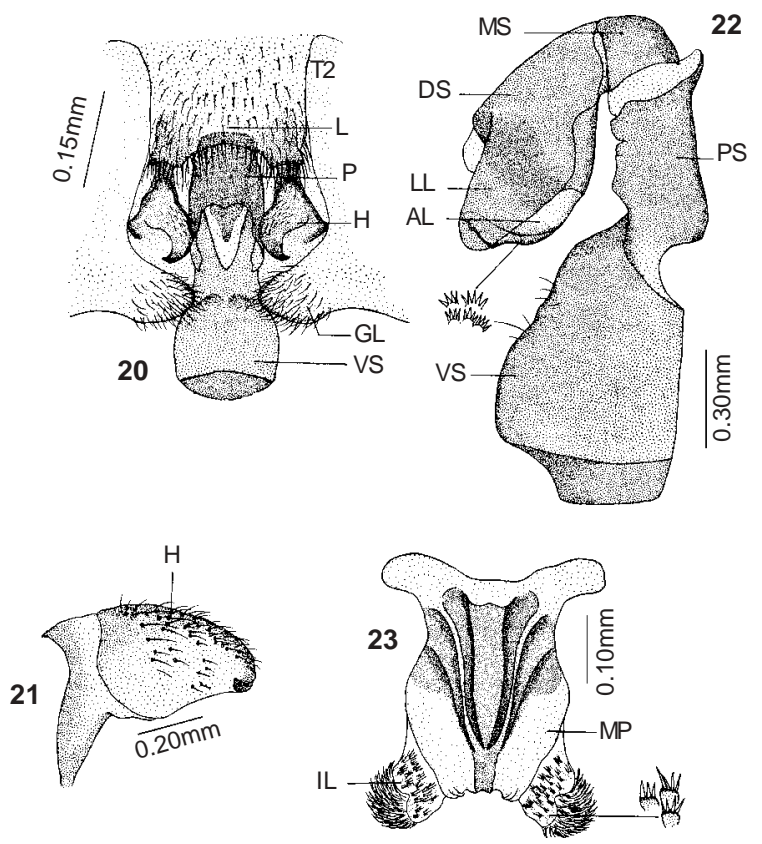

Figures 20-23. Male genitalia of Selysiothemis nigra 20 - Male genitalia (intact); 21 - Hamule (lateral view); 22 - Penis (lateral); 23 - Medial process (dorsal view)

\section{Pantala flavescens (Fabricius)}

Fabricius, 1798. Ent. Syst. Suppl., 1798: 285. (Figs. 24-30)

Lamina projecting straight out, deeply fissured in middle forming two tongue shaped lobes, furnished with long slender setae; hamule with small indistinct posterior base, anterior hamular hook small, inwardly curved, a small subapical crescent shaped median bulge on outer surface, visible from above; genital lobes small, short and rounded besetted with small setae; vesicula spermalis broad and swollen, besetted with slender setae dorsolaterally, few stiff and pointed setae arising from a crescent shaped carina apicolaterally; penis with distal segment very broadly fused with middle segment and lying closely apposed with proximal segment; distal segment almost squarish in outline; lateral lobes large, flattened, foliate structures, well sclerotized, flanging structures hiding apical lobe, joined to distal segment by a narrow long stem, apex of lobe reaching upto middle of vesicula spermalis in resting position; flagellum very long, whip like, ending in a large barb, resting between flaps in uninflated penis; apical lobe forming a dorsally evaginating structure with a pair of sclerotized, bristled flagellar flaps.
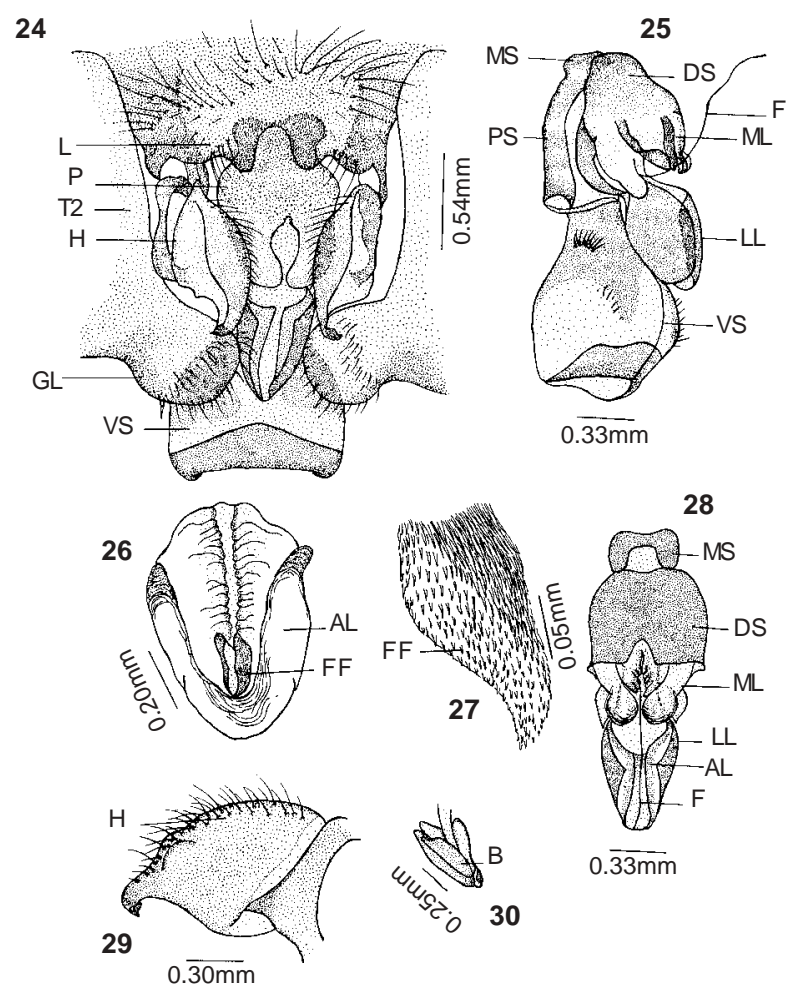

28

Figures 24-30. Male genitalia of Pantala flavescens 24 - Male genitalia (intact); 25 - Penis (lateral view); 26 - Apical lobe (dorsal view); 27 - Flagellar flap; 28 - Distal segment of penis (dorsal view); 29 - Hamule (lateral view); 30 - Barb

\section{Neurothemis fulvia (Drury)}

Rambur, 1842. Hist. Nat. Ins. Nevrop., 1842: 91. (Figs. 31-35) Lamina depressed, deeply and broadly emarginated, bearing long setae along free margin and few scattered all over dorsum; hamule with anterior hamular hook and posterior base separated by a deep cleft, setosed with long and slender setae, hook deeply curved like a sickle ending in a black spine at apex directing downwards and inwards, base projecting well beyond anterior hook posteriorwards, appearing truncated from lateral view and foliate from above; genital lobes narrowly oval, sparsely setosed with moderately long setae; vesicula spermalis short and globular, setosed with short setae mediolaterally and a tuft of them more towards distal end on either lateral side; penis with middle and proximal segments well demarcated; distal segment as long as middle and proximal segments taken together, slender at base, gradually broadening towards apex, latter reaching upto middle of vesicula spermalis at rest; dorsal hood well developed; lateral lobes moderately long, slender, flattened structures with rounded apices; medial process extended medially forming extensively inflatable lobe, bearing numerous, long and single bristles along apical border, bristles bulbous at base, then constricted and finally tapering acutely towards apices like a spine; apical lobe inflatable, very spinose, spines acutely pointed at apices. 

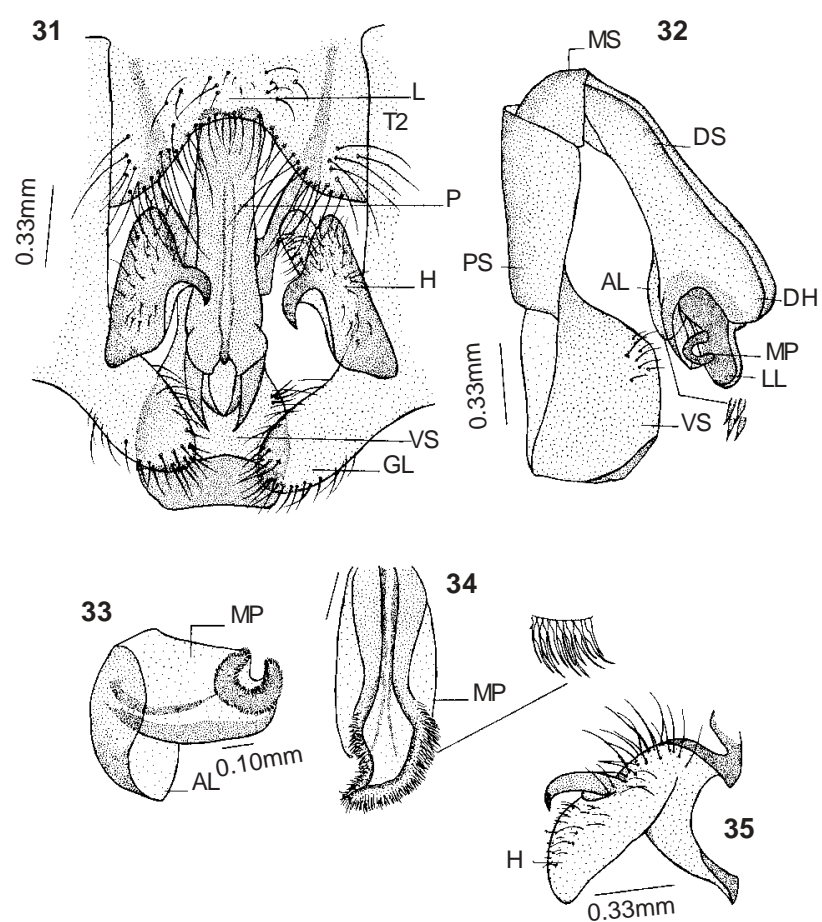

Figures 31-35. Male genitalia of Neurothemis fulvia 31 - Male genitalia (intact); 32 - Penis (lateral view); 33 - Medial processtapical lobe (lateral view); 34 - Medial process (dorsal view); 35 - Hamule (lateral view)

\section{Potamarcha congener (Rambur)}

Rambur, 1842. Hist. Nat. Ins. Nevrop., 1842: 64. (Figs. 36-39) Lamina broad, with posterior border crenulate, besetted with numerous black denticles on dorsum and moderately long setae along margin; hamule with posterior base extending posteriorly, hamular hook small, strongly curved furnished with small setae; genital lobes small and circular, bearing several rows of closely spaced small, spine like setae; vesicula spermalis large and elongated, flask shaped, bearing a tuft of few setae on either lateral side towards distal end; penis with middle and proximal segments not fused; lateral lobes inconspicuous, fused with apical lobe, latter bilobed and spinose; medial process highly inflatable bearing a pair of weak, unsclerotized whip like highly flexible cornua carrying no spines, formed from strap like structures rolled into a tube, leaving a longitudinal slit like opening.

\section{Bradinopyga geminata (Rambur)}

Rambur, 1842. Hist. Nat. Ins. Nevrop., 1842: 90. (Figs. 40-44) Genitalia small and inconspicuous; lamina depressed, broadly emarginate, besetted with few sparsely scattered small setae on dorsum and numerous along free posterior margin; hamule small with short strongly curled anterior hook and somewhat triangular posterior base, apicoposterior angle bearing numerous very small stiff setae, those along anterior hook moderately long; genital lobes broad, slightly emarginate along apical margin, right angled to plane of abdomen, setosed with stiff moderately long setae; vesicula spermalis flask shaped, coated with several small, pointed setae on either lateral side; penis with middle and distal segments well separated; lateral lobes large, flattened structures
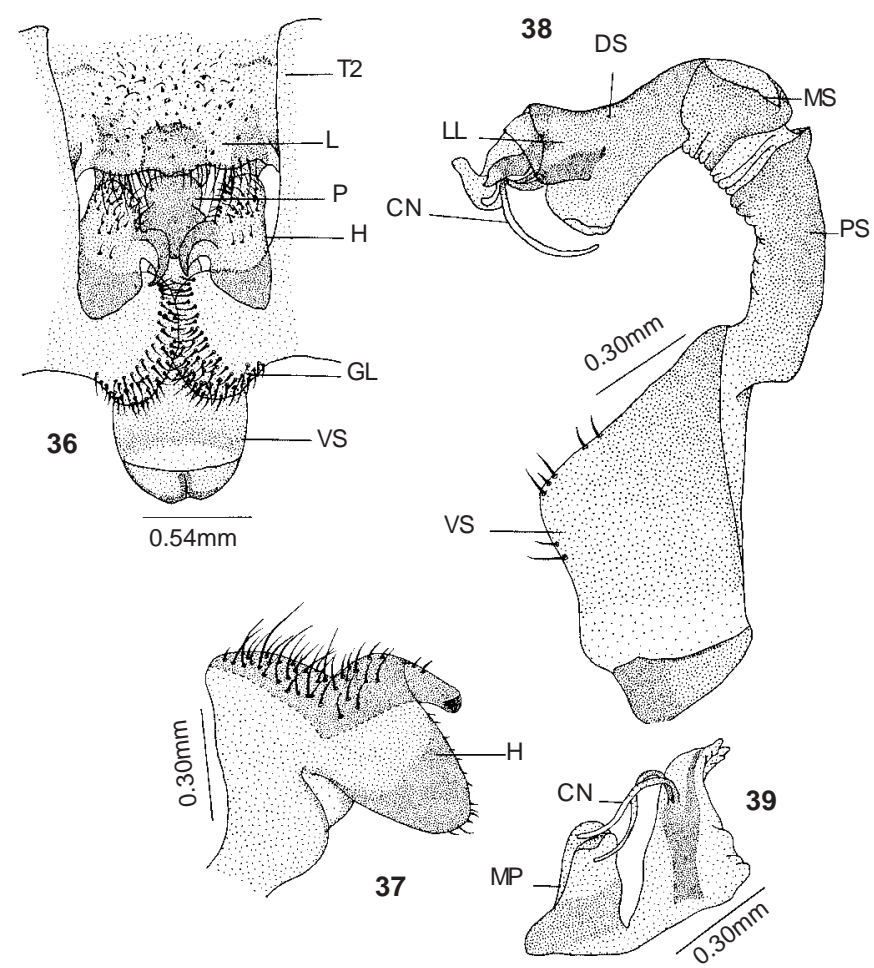

Figures 36-39. Male genitalia of Potamarcha congener 36 - Male genitalia (intact); 37 - Hamule (lateral view); 38 - Penis (lateral view); 39 - Medial process

with apical border rounded; medial process modified into a single inflatable lobe, apex rounded and bulbous, latter spinose towards lower side and only portion visible from beyond lateral lobes in lateral view; apical lobe large, highly inflatable, very spinose and bilobed.

\section{Brachythemis contaminata (Fabricius)}

Fabricius, 1793. Ent. Syst., 2: 382. (Figs. 45-50)

Lamina small, depressed, arched, small setae scattered all over dorsum and along free posterior border, very long ones arising in more or less a tuft on either lateral side close to posterior border; hamule quite small, posterior base obtusely rounded, hamular hook markedly curled, directed backwards and inwards, setosed with long but stiff setae, very small spine like setae arranged in several rows towards inner lateral surface of apicoposterior margin; genital lobes large, broad, bearing numerous stiff, spine like setae; vesicula spermalis swollen flask shaped, bearing slender setae subdorsally; penis with middle and proximal segments fused together; distal segment small, bearing a pair of large, flattened, sclerotized, globular, lateral lobes, latter furnished with multipronged bristles on inner side, enclosing a highly sclerotized 'c'-shaped structure housing flagellum and cornua; flagellum bifurcated, each flagellar branch ending in a barb; cornua crescent shaped, bearing multiramous bristles directed distally; apical lobe bilobed at apex, highly inflatable, bearing multiramous bristles. 


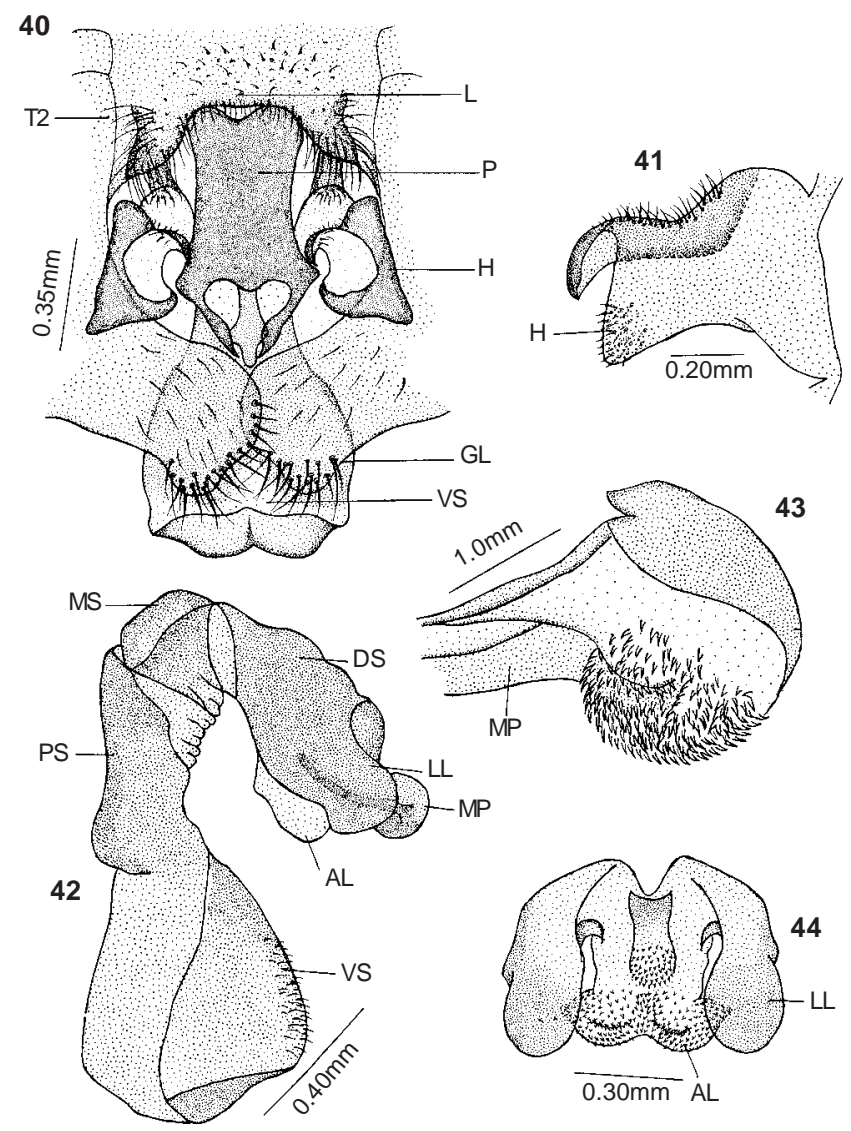

Figures 40-44. Male genitalia of Bradinopyga geminata 40 - Male genitalia (intact); 41 - Hamule (lateral view); 42 - Penis (lateral view); 43 - Medial process (apex); 44 - Lateral lobes and apical lobe

\section{Crocothemis servilia servilia (Drury) \\ Drury, 1770. Illus. Exot. Ins., 1: 112113.}

\section{(Figs. 51-55)}

Lamina depressed, strongly arched, setosed with small setae all over, more longer ones confined along posterior border; hamule elongate, hamular hook slender, strongly curved, bent inwards and backwards, separated by a deep cleft from posterior base, latter elongate, surpassing anterior hook, foliate from lateral view and truncated when seen from above, setae present on basal half of hamule long and slender, few very small ones present towards inner lateral surface subapically; genital lobes elongated, broadly rounded at apices furnished with long slender setae; vesicula spermalis small and globular, coated with very long slender setae arranged in ' $u$ ' shape on dorsum; penis with distal segment as long as middle and proximal segments taken together, latter two segments well separated; lateral lobes small but flattened plate like structures; medial process prolonged forming inflatable structure, latter trilobed at apex in deflated state, broad, capable of considerable inflation projecting well beyond small lateral lobes; apical lobe highly inflatable, appearing scoop shaped in deflated state and when viewed laterally, highly spinose, bearing acutely pointed bristles.

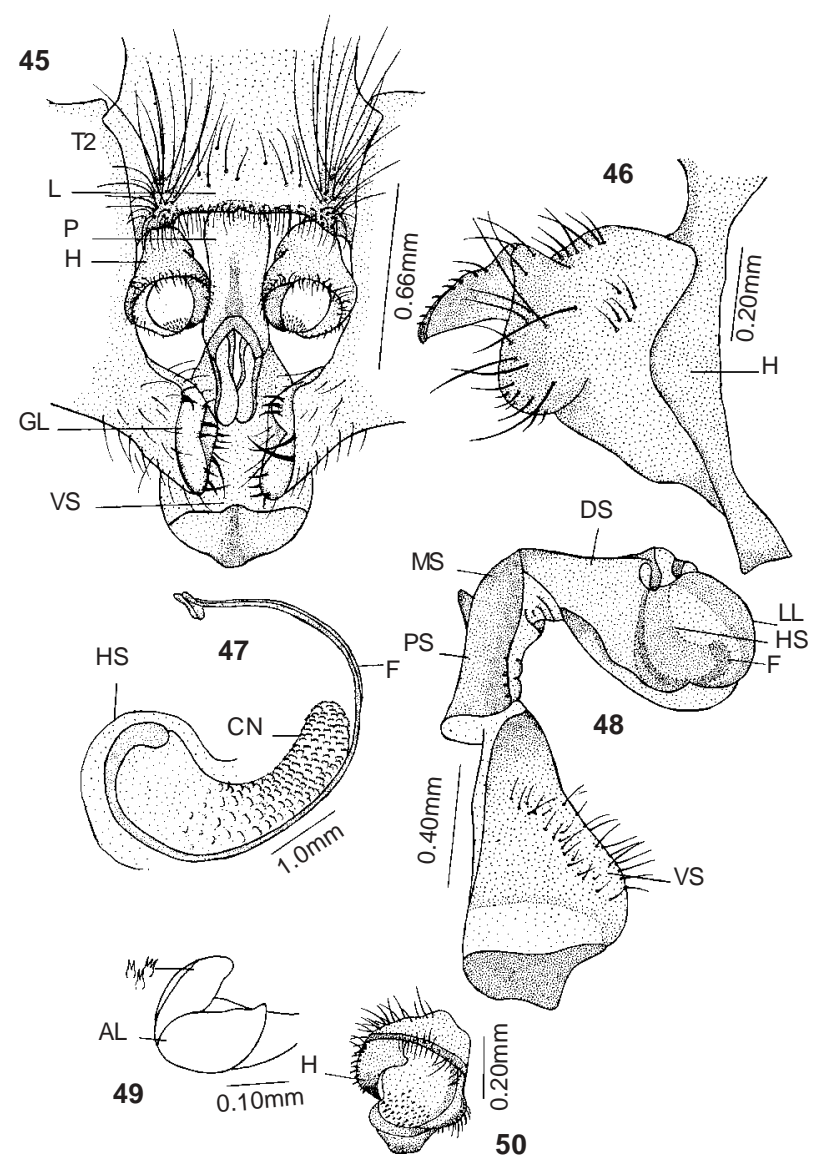

Figures 45-50. Male genitalia of Brachythemis contaminata 45 - Male genitalia (intact); 46 - Hamule (lateral view); 47 - Flagellum+cornua (housing); 48 - Penis (lateral view); 49 - Apical lobe; 50 - Hamule (dorsal view)

\section{Conclusion}

An illustrated account of the morphology of the secondary male genitalia in 11 type species of libellulid dragonflies given together with a more detailed descriptive treatment of the components of the distal segment of the penis showed that all these structures associated with secondary copulation in male dragonflies show considerable variations in shape and structure. Hamule lacks a distinct base and is roughly conical with anterior hook short, markedly curled at apices in genera Pantala Hagen and Selysiothemis Ris whereas the hamular hook is well developed and robust in genera Brachythemis Brauer, Zyxomma Rambur and Tholymis Hagen. Hamules with a large and deep cleft separating hook from posterior base is seen in genera Acisoma Rambur, Neurothemis Brauer and Palpopleura Rambur, whereas, in Brachydiplax Brauer and Potamarcha Rambur, the cleft is small and shallow. Though the three type species, Brachythemis contaminata (Fabricius), Zyxomma petiolatum Rambur and Tholymis tillarga (Fabricius) vary considerably in morphological appearance, but the study on their male genitalia showed some striking resemblances such as the distal and middle segments of penis being fused and the presence of a ' $c$ ' shaped housing concealing a long bifurcated flagellum and a pair of bristled 


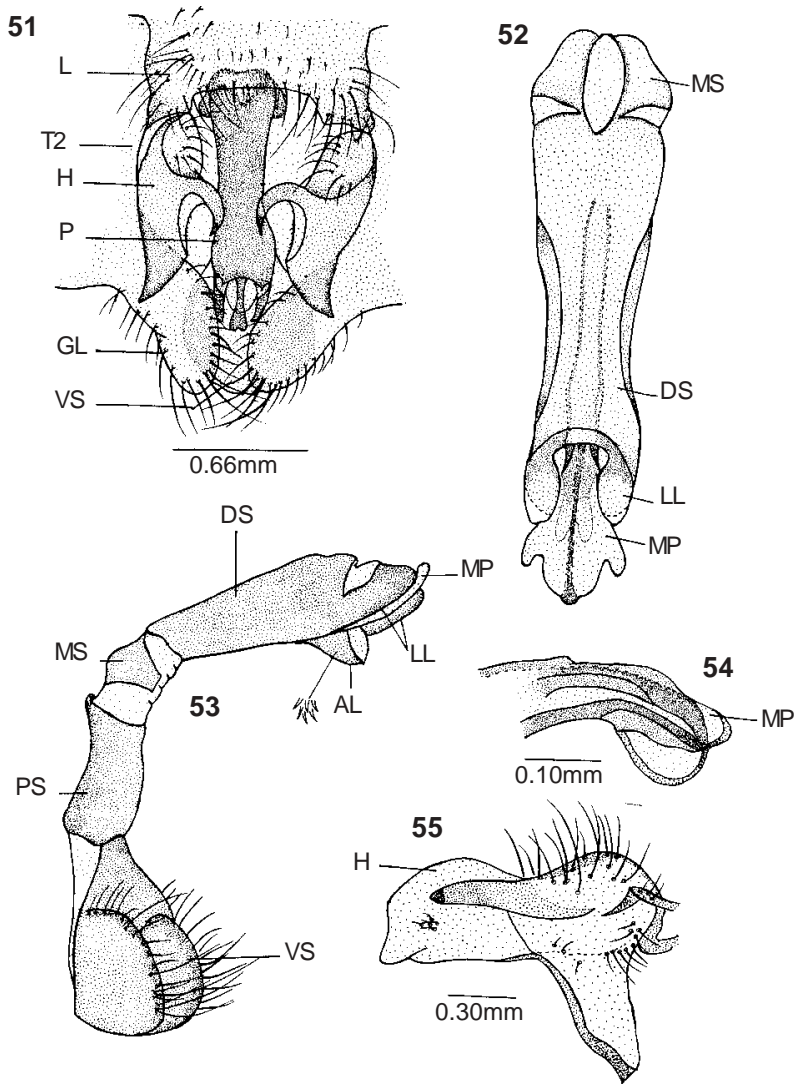

Figures 51-55. Male genitalia of Crocothemis servilia servilia 51 - Male genitalia (intact); 52 - distal segment of penis (dorsal view); 53 - penis (lateral view); 54 - medial process; 55 - hamule (lateral view)

cornua. This suggests that these species are very closely related and form a natural group. The medial process in Bradinopyga Kirby and Crocothemis Brauer is medially extended ending in a broad lobe unlike other genera where it is modified to form an assortment of lobes.

It is suggested, that during the revisionary taxonomic studies, the appropriate inclusion of the male genitalic structures of these type species to the already known diagnostic features of the respective genera, will strengthen their characterization.

\section{REFERENCES}

Andrew, R.J. and Tembhare, D.B. (1993). Functional anatomy of the secondary copulatory apparatus of the male dragonfly Tramea virginia (Odonata : Anisoptera). Journal of Morphology 218 : 99106.

Chao, H.F. (1953). The external morphology of the dragonfly Onychogomphus ardens Needham. Smith. Miscellaneous Coll. 122: 156. Cowley, J. (1937). The penis of the Chorocyphidae (Odonata) as a group character. Transactions of the Records of the Entomology Society of London 86: 118.

Drury, D. (1770). Illustrations of Exotic Insects. D. Drury, London. 30. Fraser, F.C. (1936). Fauna of British India including Ceylon and Burma. Odonata. III. Taylor \& Francis Ltd., London. 461pp.

Fabricius, J.C. (1793). Entomologia Systematica emendata et aucta. Secundum classes, ordines, genera, species adjectis synonimis, locis, observationibus, descriptionibus. C.G. Proft, Copenhagen. 519pp.
Fabricius, J.C. (1798). Supplementum entomologiae Systematicae. Proft and Storch, Copenhagen. pp. 283-286.

Kennedy, C.H. (1922). The morphology of the penis in the genus Libellula (Odonata). Entomology Newsletter 33: 33-40.

Khan, B.A. (1969). The copulatory complex of some species of Tramea Hagen (Libellulidae : Odonata) and its taxonomic importance. Zoologischer Anzeiger 181: 403-410.

Khan, B.A. (1972). The copulatory complex of some species of Ictinogomphus Cowley [=Indictinogomphus Fraser] [Odonata: Gomphidae] and its taxonomic importance. Oriental Insects 6: 75-82.

Khan, B.A. (1973). The copulatory complex of Hemianax ephippiger (Burmeister) (Aeshnidae: Anisoptera). Zoological Journal of the Linnean Society 52: 17.

Khan, B.A. (1974). The copulatory complex of Neurobasis chinensis chinensis (Linnaeus) (Agriidae: Zygoptera). Journal of the Bombay Natural History Society 71: 124-130.

Khan, B.A. (1976). The copulatory complex of Megalestes major Selys (Coenagriidae: Zygoptera). Records of the Zoological Survey of India 69: 249-254.

Lahiri, A.R. (1987). Studies on the Odonata fauna of Meghalaya. Records of the Zoological Survey of India, Occassional Paper 92: 1402.

Miller, P.L. (1981). Functional morphology of the penis of Celithemis eponina (Drury) (Anisoptera: Libellulidae). Odonatologica 10: 293-300. Miller, P.L. (1982). Genital structure, sperm competition and reproductive behaviour in some African libellulid dragonflies. Advances in Odonatology 1: 175-192.

Miller, P.L. (1984). The structure of the genitalia and the volumes of sperm stored in male and female Nesciothemis farinosa (Foerster) and Orthetrum chrysostigma (Burm.) (Anisoptera: Libellulidae). Odonatologica 13: 415-428.

Miller, P.L. (1988). Similarities in the genitalia and reproductive behaviour of male and female Tholymis tillarga (Fabr.), Parazyxomma flavecans (Martin), Brachythemis lacustris Kirby and Brachythemis leucostica(Burm.) (Anisoptera: Libellulidae). Odonatologica 17: 59-64. Miller, P.L. (1990). Mechanisms of sperm removal and sperm transfer in Orthetrum coerulescens (Fabricius) (Odonata: Libellulidae). Physiological Entomology 15: 199-209.

Miller, P.L. (1991a). The structure and function of the genitalia in the Libellulidae (Odonata). Zoological Journal of the Linnean Society 102: 43-73.

Miller, P.L. (1991b). Notes on the reproductive biology of Zyxomma petiolatum Rambur in India (Anisoptera). Odonatologica 24: 63-72.

Miller, P.L. (1995). Sperm competition and penis structure in some libellulid dragonflies (Anisoptera). Odonatologica 24: 63-72.

Prasad, M. (1988). Introduction to the external morphology of the odonate male accessory genitalia, with descriptions of sixty three cases in NorthWest Indian species. Indian Odonatology 1: 45-88.

Prasad, S.N. and Srivastava, B.K. (1960). Notes on the external genital organs of male Trapezostigma basilaris burmeisteri Kirby (Anisoptera : Odonata). Proceedings of the National Academy of Science, India 75-76. Rambur, M.P. (1842). Histoire Naturelle des Insectes, Nevropteres Librairie Encyclopedique de Poret, Paris. pp.534.

Schmidt, E. (1915). Vergleichende Morphologie des 2 und 3 Abdominal segments bei männlichen Liebellen. Zoologischen Tahrbüchern. Abteilung für Anatomie und Ontogenie der Tiere 39: 87-200.

Thompson, O.S. (1908). Appendages of the second abdominal segment of male dragonflies (Order Odonata). Report Ent. No. 23 in Albany, New York State Education Department Musc. Bulletin 124: 249-263.

Whedon, A.D. (1918). Comparative morphology and possible adaptations of the abdomen in the Odonata. Transactions of the Amererican Entomology Society 44: 373437.

\section{ACKNOWLedgments}

Thanks are due to Dr. M. Prasad, ZSI, Calcutta and Dr. Arun Kumar, ZSI, Dehradun for their help to compare the species with those available in collections in respective museums. 